\title{
Effect of Heavy Metals Accumulation of Cadmium (Cd) on Leaf Chlorophyll Green Champa (Polyaltia longifolia) in Industrial Area Makassar, South Sulawesi
}

\author{
Hardiyanti YM1, Fahruddin Fahruddin², Paulina Taba ${ }^{3}$ \\ ${ }^{1}$ Department of Environmental Management, Faculty of Graduate School, Hasanuddin University, Makassar, Indonesia \\ ${ }^{2}$ Department of Biology, Faculty of Mathematics and Natural Sciences, Hasanuddin University, Makassar, Indonesia \\ ${ }^{3}$ Department of Chemistry, Faculty of Mathematics and Natural Sciences, Hasanuddin University, Makassar, Indonesia
}

Correspondence Author: Hardiyanti YM, Department of Environmental Management, Faculty of Graduate School, Hasanuddin University, Makassar, Indonesia.

E-mail: hardiyantiymssibio@gmail.com

Received date: 17 January 2020, Accepted date: 25 March 2020, Online date: 29 March 2020

Copyright: (C) 2020 Hardiyanti YM et al. This is an open-access article distributed under the terms of the Creative Commons Attribution License, which permits unrestricted use, distribution, and reproduction in any medium, provided the original author and source are credited.

\begin{abstract}
Heavy metal pollution in the industrial area to cause problems on the vegetation growing around it. The study aims to determine the content of heavy metals Cd accumulates in the leaves Polyaltia longifolia in the industrial area Makassar. Concentrations of heavy metals Cd measurement with AAS method and the measurement of chlorophyll concentration was measured using a spectrophotometer at wavelength 649 and $665 \mathrm{~nm}$, and the results showed the concentration of heavy metals Cd accumulates in leaves Polyaltia longifolia is Cd is from 0.035 to $0.077 \mathrm{~g} / \mathrm{g}$ at (leaves $5-10 \mathrm{~cm}$ of the lower position and leaves the upper position as high as $10-25 \mathrm{~m}$. Then the chlorophyll concentration is $13.51-26.83 \mathrm{ug} / \mathrm{g}$ (chloropyll leaves $5-10 \mathrm{~cm}$ of the lower position and leaves the upper position as high as 10-25 m. heavy metals Cd affect the levels of chlorophyll in the leaves Polyaltia longifolia (leaf upper position) that $F_{\text {.hitung }}>$ of the $F_{\text {.tabel }}$ with a value of 0.310 $>0.05$ means did not show any significant damage $(>0.05)$. While, heavy metals Cd in Polyaltia longifolia leaf (leaf lower position) that $F_{\text {'hitung }}<$ of the $F_{\text {tabel }}$ with a value of $0.02<0.05$ means shows the damage significantly.
\end{abstract}

Keywords: Accumulation, Cd, chlorophyll, pollution, industrial.

\section{INTRODUCTION}

The living environment significantly affects living things in the surrounding conditions [1]. One of the environmental problems that environmental pollution in the form of heavy metal pollution, especially in the air and is closely related to human activities, the processing of the products are side effects polluters that pollute the air to the environment [2]. The existence of industries in Indonesia influences environmental conditions around the place of establishment of industrial buildings [3].

Various industrial uses of power and heat from the combustion of coal and gasoline. Regulation of the Governor of South Sulawesi No. 69 the Year 2010 on ambient air quality standard, the material of air pollution originating from the industry coming out of the chimney is $\mathrm{CO}, \mathrm{SO}_{2}, \mathrm{NO}_{\mathrm{X}}$, and pollutants in the form of compounds containing heavy metals such as cadmium (Cd) [4], [5]. Heavy metal pollutants contained in the dust floating in the ambient air will be partially attached to the plant, especially on the leaf, as the blade is part of the plant is very sensitive to air pollution and most often exposed to the air pollution [6]. In this case, the need for plants that are potential accumulators as bioremediation agents in addressing air pollution indicators $[7]$.

Plants are used plant protector road, with trees Polyalthia longifolia. These plants have strong roots so resistant to damage from human activities, and it is easy to grow in hot and wind-resistant, making it suitable to use as a plant protector road capable of absorbing elements of air pollutants without damage or impaired growth [8].

Based on this background, so in this study, conducted an observational study of leaves of trees Polyaltia longifolia to determine the extent of leaves roadside able to accumulate heavy metals cadmium $(\mathrm{Cd})$ and whether the metal accumulation causes the effect on leaf organs. 


\section{MATERIALS AND METHODS}

\section{Sampling}

The samples Polyalthia longifolia covers the leaves in the lower position and leaves the upper position. Purposive random sampling in the Industrial area Makassar (Fig. 1) at three locations. Station S1 (first sampling distance); S2 (second sampling distance) and S3 (third-sampling distance).

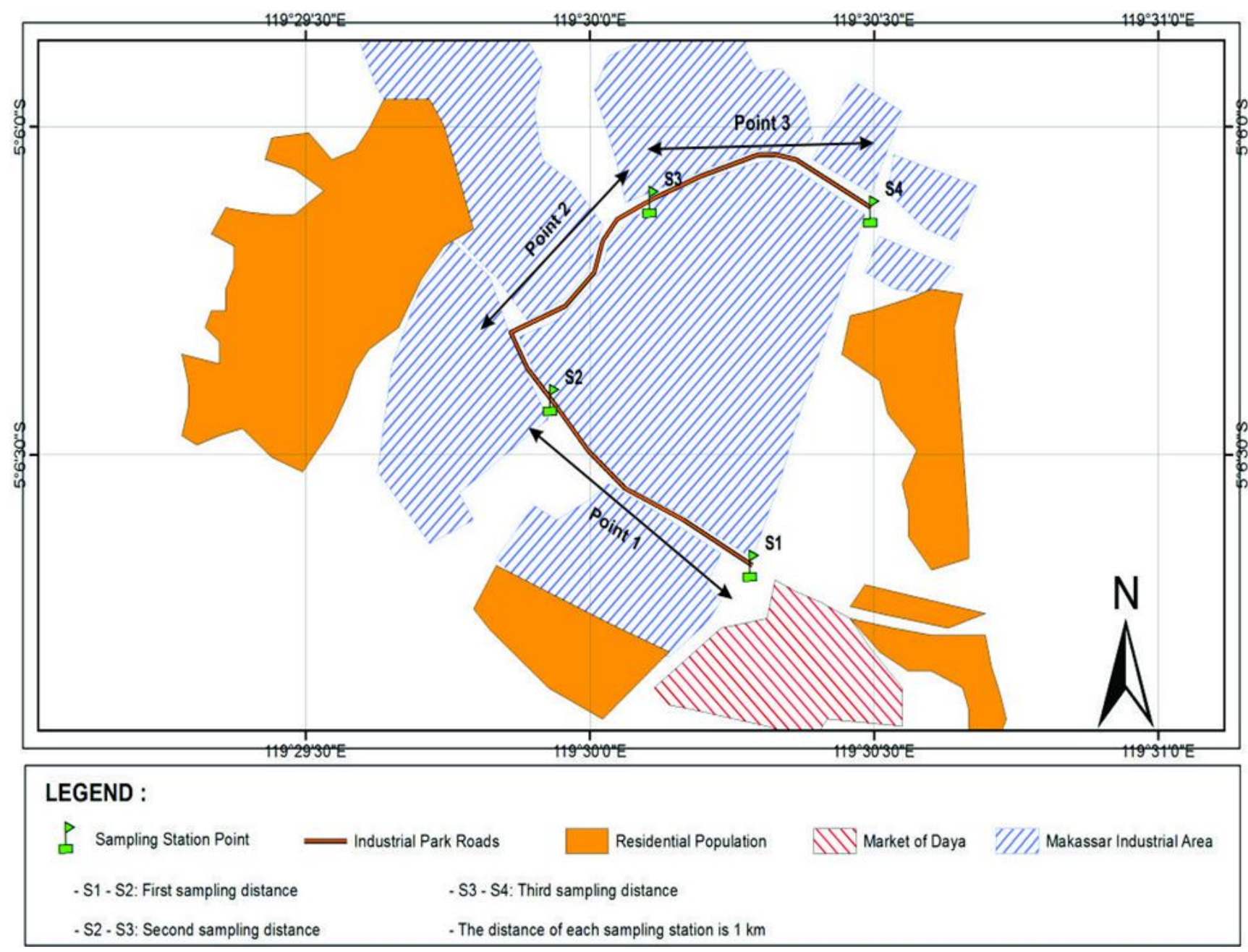

Fig. 1: Sampling location on Makassar Industrial Area

\section{Measurement of Concentration of Cadmium (Cd)}

Using Atomic Absorption Spectrophotometer. Polyalthia longifolia leaf samples that have been dried be ignored in a furnace at $600^{\circ} \mathrm{C}$ for 24 hours, then given $100 \mathrm{~mL}$ of demineralized water in a beaker and $5 \mathrm{~mL}$ concentrated $\mathrm{H}_{2} \mathrm{SO}_{4}(65 \%)$. The mixture is heated at a temperature of $20^{\circ} \mathrm{C}$ until the sample reached a $10 \mathrm{ml}$ beaker, filtered, and added to mark boundaries aquabides 100 $\mathrm{mL}$ flask. Levels of cadmium (Cd) in the solution were measured at Atomic Absorption Spectrophotometer.

\section{Total Chlorophyll Content}

Measurements of chlorophyll in the leaves Polyalthia longifolia using a UV spectrophotometer based on the optical density (OD) [9]. The leaves are extracted with $95 \%$ alcohol, then shaken using a vortex and then centrifuged for 10 minutes at a speed of $4000 \mathrm{rpm}$. Measured absorbance at wavelengths of 649 and $665 \mathrm{~nm}$. The total chlorophyll content was calculated by the formula Wintermans and De Mots:

Chlorophyll a $(\mathrm{mg} / \mathrm{L})=(13.7 \times$ OD665) $-(5.76 \times$ OD649)

Chlorophyll b $(\mathrm{mg} / \mathrm{L})=(25.8 \times$ OD649) $-(7.7 \times$ OD665)

Total chlorophyll $(\mathrm{g} / \mathrm{mL})=20.0+6.1$ OD665 OD649.

Description: OD (optical density) or chlorophyll absorbance values

\section{Data Analysis}

The experimental data on the absorption capability of cadmium (Cd) by leaf, Polyalthia longifolia reviewed based on chlorophyll levels will be analyzed in a simple linear regression to see the correlation coefficient between the concentration of heavy metals $\mathrm{Cd}$ in leaf Polyalthialongifolia these parameters. ANOVA performed using SPSS statistical tools. 


\section{RESULTS AND DISCUSSION}

\section{The concentration of Heavy Metals Cd}

Levels of heavy metals carried on Polyalthia longifolia leaves. The upper position with the code S1A, S2A, S3A as high as 10$25 \mathrm{~m}$. Leaves the lower position with the code S1B, S2B, S3B height of 5-10 m, the result is S1A with a value of $0.035 \mu \mathrm{g} / \mathrm{g}$; S1B with a value of $0.042 \mu \mathrm{g} / \mathrm{g}$; S2A with a value of $0.049 \mu \mathrm{g} / \mathrm{g}$; S2B with a value of $0.049 \mu \mathrm{g} / \mathrm{g}$; S3A with a value of 0.077 $\mu \mathrm{g} / \mathrm{g}$ and $\mathrm{S} 3 \mathrm{~B}$ to the amount of $0.070 \mu \mathrm{g} / \mathrm{g}$ (Fig. 2).

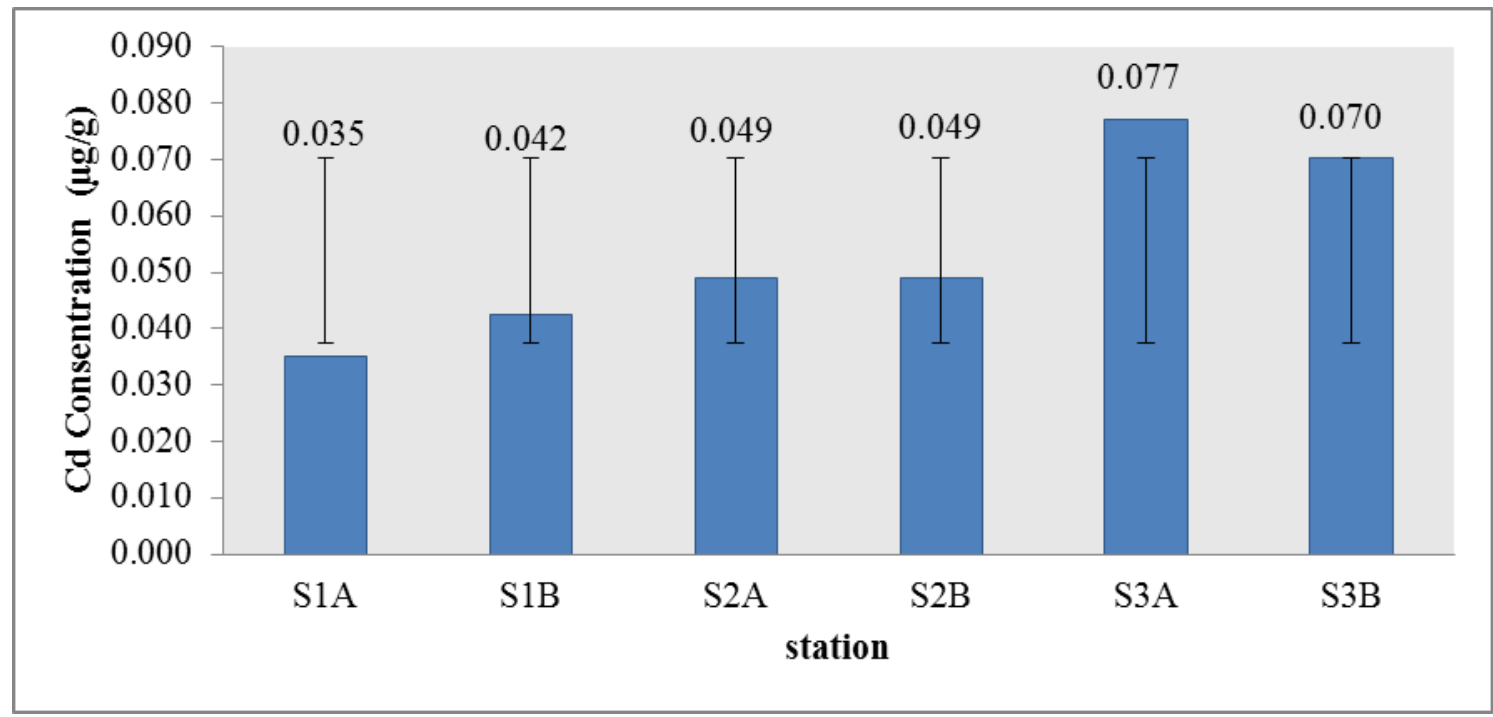

Fig 2. The concentration of heavy metals Cd in Polyalthia longifolia leaves at each station: S1 (station 1); S2 (station 2); S3 (station 3); A (leaf upper positions); B (leaf lower positions).

\section{Measurement of Leaf Total Chlorophyll Content}

Polyalthia longifolia of leaf total chlorophyll content in extraction using Novaspec type III spectrometer at $\lambda 649$ and $665 \mathrm{~nm}$. Samples were analyzed, namely levels of total chlorophyll in leaves exposed the upper position and the lower position in the area of industrial pollution, the result is S1A with value $13.51 \mu \mathrm{g} / \mathrm{g} ; \mathrm{S} 1 \mathrm{~B}$ with a value of $16.60 \mu \mathrm{g} / \mathrm{g} ; \mathrm{S} 2 \mathrm{~A}$ with a value of $10.89 \mu \mathrm{g} / \mathrm{g}$; S2B with a value of $19.38 \mu \mathrm{g} / \mathrm{g} ; \mathrm{S} 3 \mathrm{~A}$ with a value of $26.83 \mu \mathrm{g} / \mathrm{g}$; S3B with a value of $26.16 \mu \mathrm{g} / \mathrm{g}$; KA with a value of 15.34 $\mu \mathrm{g} / \mathrm{g}$; and $\mathrm{KB}$ with a value of $7.81 \mu \mathrm{g} / \mathrm{g}$ (Fig. 3).

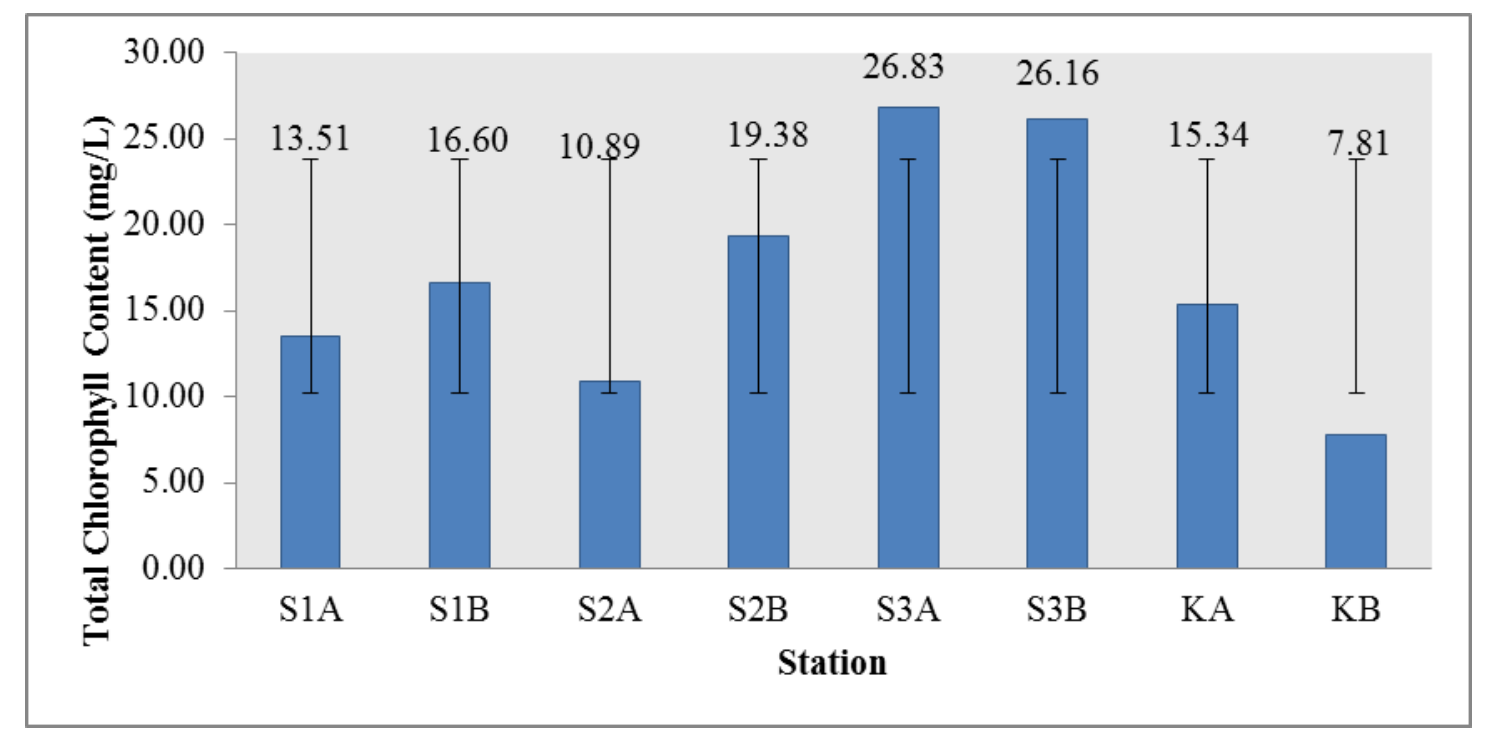

Fig 3. Levels of total chlorophyll in the upper leaves on each station: S1A (station 1 leaves upper positions). Leaves the lower of each station: S1B (station 1 leaves lower positions); S2A (station 2 leaves upper positions); S2B (station 2 leaves lower positions); S3A (station 3 of leaves upper positions); S3B (station 3 of leaves lower positions). Controls: KA (control / unexposed leaves upper positions); and KB (Control/ unexposed leaves lower positions). 


\section{Effect of Cadmium (Cd) to the level of Total Chlorophyll}

Analysis of the effect of $\mathrm{Cd}$ on levels of total chlorophyll by using statistical analysis simple linear regression test can be seen in (Fig. 4). The simple direct regression test to see the effects of these two variables. Then determine the value of $F_{\text {table }}$ and $F_{\text {count }}$ on Spss. The amount of influence on Cd concentration of the total chlorophyll content based on the value of the square of $\mathrm{R}$ and $\mathrm{R}^{2}$.

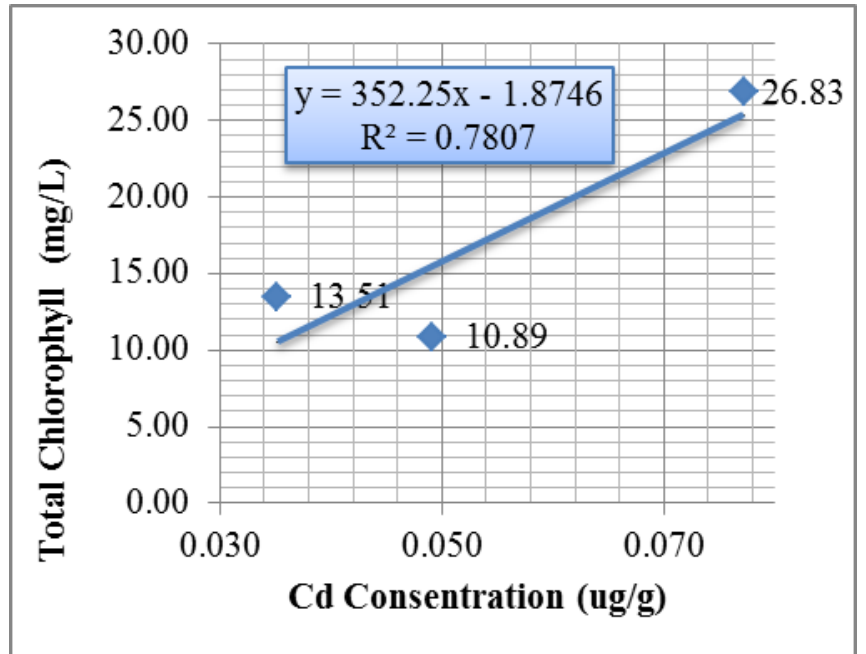

(A)

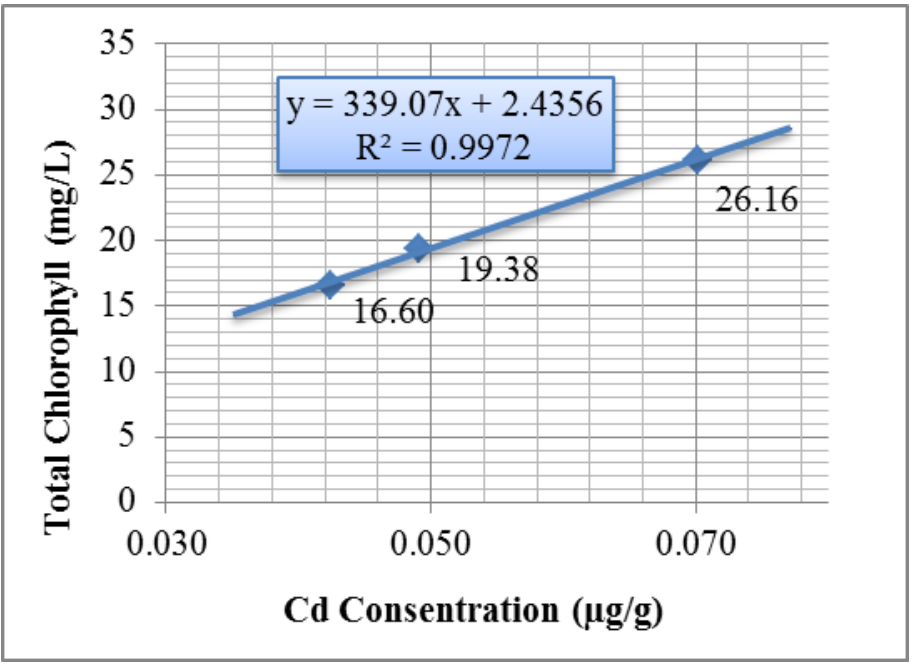

(B)

Fig 4. (a) The effect of Cd on chlorophyll levels in the leaves Polyalthia longifolia (upper leaf positions). (b) Analysis of Effect of Cd on chlorophyll levels in the leaves Polyalthia longifolia (leaf lower position).

\section{DISCUSSION}

Based on the analysis of the effect of $\mathrm{Cd}$ on the chlorophyll content by using statistical analysis simple linear regression test of the obtained results that the value of the square $\mathrm{R}^{2}$ of 0.780 . Effect of heavy metals concentration Cd on chlorophyll content in leaves by $78 \%$. This means that there are significant concentrations of heavy metals $\mathrm{Cd}$ on total chlorophyll content in the leaves that other variables influence the remaining $22 \%$. This suggests that $F_{\text {.hitung }}>$ of the $F_{\text {tabel }}$ with a value of $0.310>0.05$ means insignificant. This means that although the concentration of heavy metals $\mathrm{Cd}$ on chlorophyll content in leaves by $78 \%$ but the results were not sustained significant damage.

The study by Liu (2014) [10], the declining trend of chlorophyll content in the leaves Gossypium hirsutum L. Show shape its response to pollutants in the environment, including heavy metals Cd. Although Gossypium hirsutum L. total chlorophyll content showed a declining trend in line with the increase in the concentration of $\mathrm{Cd}$ in the leaves, the value of the correlation coefficient is minimal. So it can be said that the level of $\mathrm{Pb}$ does not affect the leaf chlorophyll content.

Furthermore, analysis of the effect of $\mathrm{Cd}$ on the total chlorophyll content by using statistical analysis simple linear regression test of the obtained results that the value of the square $\mathrm{R}^{2}$ of 0.997 . Effect of heavy metals concentration Cd on total chlorophyll content in leaves of $99 \%$. This means that there are significant concentrations of heavy metals Cd on total chlorophyll content in leaves. And the remaining $1 \%$ is influenced by other variables. Based on the research that $\mathrm{F}_{\text {.hitung }}<$ of the $\mathrm{F}_{\text {tabel }}$ with a value of $0.02<0.05$ means significant. This means that the concentration of heavy metals Cd on chlorophyll content in leaves of $99 \%$ and substantial, sustained damage.

The study by Liu (2014) [10], the higher the effect of heavy metals on total chlorophyll content, then the damage to the leaf tissue will suffer significant damage because the chlorophyll in the leaves will damage the structure of chloroplasts during the process photosynthesis [11]. Chloroplast structure formation is strongly influenced by mineral nutrients such as $\mathrm{Mg}$ and Fe. The excessive influx of heavy metals in plants will reduce the intake of $\mathrm{Mg}$ and $\mathrm{Fe}$, causing changes in the volume and number of chloroplasts as an ingredient of green in the stems and leaves, yellowing and eventually led to the experience of chlorosis and chlorotic symptoms [12] [13].

\section{CONCLUSIONS}

The concentration of heavy metals Cd accumulates in the leaves Polyaltialongifolia in the Industrial city of Makassar are heavy metals $\mathrm{Cd}$ affect the levels of chlorophyll in the leaves Polyaltialongifolia (upper leaf position) that $\mathrm{F}_{\text {.hitung }}>$ of the $\mathrm{F}_{\text {tabel }}$ with a value of $0.310>0.05$ means did not show any significant damage $(>0.05)$. While the heavy metal cadmium $(\mathrm{Cd})$ on Polyalthia longifolia leaf (leaf lower position) it $\mathrm{F}_{\text {.hitung }}<$ of the $\mathrm{F}_{\text {.tabel }}$ with a value of $0.02<0.05$ means shows the damage significantly.

\section{ACKNOWLEDGEMENT}

The authors are grateful to our friends Environmental Management, at Hasanuddin University graduate school on the overwhelming support in the field and laboratory work. 


\section{REFERENCES}

[1] Fisher-Vanden, K., Y. Hu., G. Jefferson., M. Rock and M. Toman., 2016. Factors affecting energy in four Chinese industries. Energy J, 37:153-178.

[2] Tauqeer, M.H., S. Ali., K. Sardar., S. Hameed., S. Afzal., S. Fatima., B.M. Shakoor and U.S. Bharwana., 2013. Heavy Metal Contamination and What are the Impacts on Living Organisms., Department of Environmental Sciences, Government College University, AllamaIqbal Road, 38000, Faisalabad, Pakistan. Greener Journal of Environmental Management and Public Safety, 2(4):172-179.

[3] Chen, S., X. Du., J. Huang and C. Huang,. 2019. The Impact of Foreign and Indigenous Innovations on China's Industrial Energy Intensity. J. Sustainability, 11(4):11-12.

[4] Zhao, P.S., F. Dong., D. He., X.J. Zhao., X.L. Zhang., W.Z. Zhang., Q. Yao and H.Y Liu., 2013. Characteristics of concentrations and chemical Compositions for PM2.5 in the region of Beijing, Tianjin and Hebei, China. Journal of Atmosphere. Chemistry. Physics, 8(13). ISSN: 4631-4644.

[5] Huang, J., J. Wu., Y. Tang,. 2020. Effect of openness on the intensity of Chinese $\mathrm{CO}_{2}$ Industry.Pollut Sci Environ Res, 2(12):54-55.

[6] Aalto,J, E. H. Riihimäki., K. Meineri and M, Luoto., 2017. Revealing Topoclimatic heterogeneity Using Meteorological Station Data. International Journal of Climatology, 37(13):544-566. ISSN: 0899-8418.

[7] Baciak M, P. Sikorski., A. Piotrowicz-Cieslak., B. Adomas., 2017. Role of decarboxylases in the biosynthesis of biogenic amines of pea growing in soil Contaminated with lomefloxacin. Ecol Appl Environ Res, 15 (3): 1131-1148.

[8] Mukherjee, A., M. Agrawal,. 2016. Pollution Response Score of Tree Species in Relation to Ambient Air Quality in an Urban Area Contam. Bull Environ Toxicol, 96:197-202.

[9] Liu, D., X. Liu., Z. Chen., H. Xu., and X. Ding,. 2010. Bioaccumulation of Lead and the Effects of Lead on Catalase Activity, Glutathione Levels, and Chlorophyll Content in the Leaves of Wheat. Journal of Communications in Soil. Science and Plant Analysis, 41(8):935-944.

[10] Liu L., S. Hongchun,. C. Jing,. Z. Yongjiang., L. Dongxiao, L. Cundong,. 2014. Effects of Cadmium (Cd) on Seedling Growth Traits and Photosynthesis Parameters in Cotton (Gossypium hirsutum L.). Omics jurnal, 7(4), 284-290. ISSN: 1836-3644.

[11] Poul, E. Jensen and L. Dario,. 2014. Chloroplast evolution, structure and functions of Heavy Metal. Journal of Prime reports, 6(40).

[12] Ana, F. López-Millán, D. Duy, and K. Philippar,. 2016. Chloroplast Iron Transport Proteins - Function and Impact on Plant Physiology. Front Plant Sci, 7(178).

[13] Fahruddin. F and R. E. Tanjung,. 2019. The study of bacteria populations in phytoremediation of cadmium using Eichhornia crassipes. Journal of Physics: Conference Series. 1341. 